\title{
The Ability of Elementary School Students in Compiling Puzzles on the Pancasila Symbol Material
}

\author{
Ilmawati Fahmi Imron 1 \\ DOI: $10.35445 /$ alishlah.v13i1.257
}

\begin{abstract}
Article Info
Abstract

Keywords:

Students' Ability

Puzzle

Pancasila's Simbol

The purpose of this study was to analyze the students' ability to construct a puzzle of Pancasila' symbols by applying the STAD learning's model to grade 1 students at SDN Gayam 3 Kediri. The method used in this research is descriptive qualitative. Data collection techniques are in the form of teacher and student observations, results of field notes, and documentation. Based on the research results with reference to the research instrument in the form of teacher observation data with a percentage of $73.6 \%$ then observation of student activity with a percentage of $64.2 \%$, then based on the results of field notes and documentation it was stated that grade 1 students of SDN Gayam 3 Kediri were able to compile a puzzel Pancasila symbols with PPKn material even though there are still deficiencies. These shortcomings come from teachers, school infrastructure, and students themselves.
\end{abstract}

Kata kunci:

Kemampuan Siswa

Puzzle

Simbol Pancasila

\begin{abstract}
Abstrak
Tujuan dalam penelitian ini untuk menganalisis kemampuan siswa dalam menyusun puzzle simbol-simbol Pancasila dengan menerapkan model pembelajaran STAD pada siswa kelas 1 di SDN Gayam 3 Kediri. Metode yang digunakan dalam penelitian ini adalah deskriptif kualitatif. Teknik pengumpulan data adalah berupa hasil observasi guru dan siswa, hasil catatan lapangan, dan dokumentasi. Berdasarkan hasil penelitian dengan mengacu pada instrumen penelitian berupa data hasil observasi guru dengan persentase $73,6 \%$ kemudian observasi aktivitas siswa dengan persentase $64,2 \%$, selanjutnya berdasarkan hasil catatan lapangan dan dokumentasi dinyatakan bahwa siswa kelas 1 SDN Gayam 3 Kediri telah mampu menyusun puzzel simbol-simbol Pancasila dengan materi PPKn meskipun masih terdapat kekurangan-kekurangan. Kekurangan tersebut dari guru, sarana-prasarana sekolah, dan siswa sendiri.
\end{abstract}

\section{PENDAHULUAN}

Pendidikan Pancasila dan Kewarganegaraan (PPKn) pada prinsipnya memiliki tujuan untuk mengembangkan sikap dan nilai moral siswa guna menyiapkan warga negara Indonesia yang lebih baik (a good citizen), berpartisipasi aktif dan bertanggungjawab dalam kegiatan bermasyarakat, berbangsa dan bernegara. Ibda (2012) menjelaskan bahwa melalui PPKn diharapkan semua unsur

\footnotetext{
${ }^{1}$ Universitas Nusantara PGRI Kediri, Jawa Timur, Indonesia Email: ilmawati@unpkediri.ac.id

Vol.13 (1) June, 2021

Received: October 6, 2020; Received in revised form: January 1, 2021; Accepted: January 12, 2021; Available online: March 30, 2021

This is an open access article under a Creative Commons Attribution-NonCommercial-ShareAlike 4.0 International License
} 
dalam lembaga pendidikan termasuk guru dan siswa dalam berperilaku mencerminkan nilai-nilai luhur Pancasila.

Pancasila selain merupakan dasar negara Indonesia juga merupakan tonggak utama dalam membentuk kepribadian siswa. Namun saat ini, masih banyak siswa yang kurang memahami bahkan tidak mengetahui makna simbol-simbol dan sila-sila Pancasila khususnya pada jenjang sekolah dasar. Masa pendidikan dasar merupakan masa gemilang yang seharusnya konsep-konsep yang bermanfaat untuk masa depan anak diberikan pada masa ini. Masa sekolah dasar adalah masa yang paling baik untuk mengajarkan dan mendidik siswa agar siswa mengetahui, memahami hingga mampu mengamalkan sila-sila dalam pancasila dalam kehidupan sehari-harinya.

Pentingnya siswa sekolah dasar memahami makna dan simbol Pancasila adalah agar siswa mampu memahami ideologi negara Indonesia dan mampu mengamalkan perilaku yang mencerminkan nilai-nilai Pancasila ke dalam kehidupan sehari-hari anak baik di sekolah maupun di rumah. Apabila dari usia sekolah dasar anak sudah diperkenalkan mengenai simbol-simbol Pancasila dan makna dari simbol-simbol tersebut, maka akan lebih mudah bagi anak tersebut untuk mengamalkan Pancasila di kehidupannya yang tentunya memerlukan pendampingan dari orang tua dan guru kelas, serta harapannya pembelajaran tersebut akan menjadi dasar untuk membentuk dan mempersiapkan generasi muda yang Pancasilais.

Adapun indikator perilaku siswa yang dapat mencerminkan sila Pancasila adalah melakukan kerjasama dengan teman sekelasnya, menghormati guru, belajar menghargai pendapat temannya serta hormat pada orang tuanya, saling menghargai dengan teman yang berbeda suku dan rasnya, memberikan kebebasan temannya untuk memeluk agama yang diyakininya tanpa dipaksa dan di caci, dan sebagainya.

Sesuai dengan Peraturan Menteri Pendidikan dan Kebudayaan No 21 Tahun 2016 tentang Standar Isi Pendidikan Dasar dan Menengah, ruang lingkup materi PPKn untuk pendidikan dasar kelas rendah diantaranya adalah makna simbol-simbol Pancasila dan lambang negara Indonesia. Konsep materi yang terkandung pada muatan PPKn kelas rendah apabila diajarkan dengan menggunakan model dan media yang mendukung akan lebih berkesan dan bermakna bagi siswa, sehingga dapat meningkatkan kemampuan siswa dalam menangkap setiap materi pembelajaran. Pembelajaran akan bermakna apabila siswa terlibat langsung dalam proses belajar mengajar dengan memperhatikan prinsip belajar (Yunita, 2016).

Menurut Hamzah (2009: 23) menyebutkan prinsip belajar pada proses belajar yang bermakna yakni 1) prinsip perbedaan individu dalam belajar, 2) prinsip perhatian dan motivasi, 3) prinsip keaktifan, 4) prinsip keterlibatan, 5) prinsip balikan dan penguatan. Melalui prinsip-prinsip belajar tersebut, seseorang akan memperoleh pengalaman langsung pada ranah pengetahuan/kognitif, sikap/afektif dan keterampilan/ psikomotorik. Karakteristik siswa Sekolah Dasar pada umumnya adalah senang bermain, senang bergerak, senang bekerja dalam kelompok dan senang merasakan atau memperagakan sesuatu secara langsung. Dengan karateristik siswa inilah dapat diketahui kemampuan siswa dalam ranah kognitif, afektif maupun psikomotor. Oleh karena itu perlu melakukan pembaharuan dalam proses pembelajaran agar lebih berpusat pada siswa dengan melibatkan siswa secara aktif dalam proses pembelajaran melalui media pembelajaran yang bertujuan untuk meningkatkan kemampuan siswa.

Kemampuan siswa sekolah dasar berbeda-beda antara anak yang satu dengan anak yang lain. Kemampuan anak pada kelas rendah dan kelas tinggi pun berbeda dilihat dari proses pembelajaran anak. Siswa kelas rendah masih membutuhkan bimbingan secara penuh untuk mengembangkan kemampuan kognitif, afektif maupun psikomotornya agar dapat berkembang secara optimal. Salah satu karakteristik belajar siswa kelas rendah adalah belajar dari hal-hal konkret atau nyata, yakni yang dapat dilihat, didengar, dibaui, diraba dan diotak-atik dengan titik penekanan pada pemanfaatan lingkungan sebagai sumber belajar.

Salah satu media pembelajaran yang dapat digunakan di kelas rendah adalah media puzzle. Media puzzle adalah suatu gambar yang dibagi menjadi potongan-potongan gambar yang bermakna 
(Latut, Anirisa. 2017:4). Manfaat puzzle bagi siswa menurut Mungarofatul, Siti (2012: 11) diantaranya ialah meningkatkan keterampilan kognitif, meningkatkan keterampilan motorik halus, meningkatkan keterampilan sosial. Sejalan dengan pernyataan tersebut, Rosdijati (2012: 40) menyatakan bahwa media puzzle memiliki keunggulan, diantaranya melatih psikomotorik, melatih daya ingat siswa, suasana kelas menjadi bergairah, adanya interaksi positif, siswa termotivasi melakukan kegiatan, siswa mampu bekerjasama dalam kelompok. Dengan demikian, penggunaan media puzzle dalam pembelajaran PPKn pada materi simbol-simbol Pancasila dapat membantu siswa dalam memahami dan meningkatkan perhatian siswa terhadap materi yang diajarkan.

Penelitian terdahulu juga dilakukan oleh Hastuti (2019) menggunakan media puzzle pancasila, pada penelitiannya yang merupakan penelitian tindakan kelas, terjadi peningkatan dari siklus 1 hingga siklus 3. Hal ini membuktikan bahwa pembelajaran PPKn dengan menggunakan media puzzle mampu meningkatkan kemampuan siswa dalam materi Pancasila. Oleh sebab itu, peneliti memandang perlu dilakukan penelitian untuk menganalisis kemampuan siswa dalam menempelkan atau menyusun puzzle simbol-simbol Pancasila dan mencocokkan simbol Pancasila dengan bunyi sila Pancasila beserta pengamalannya pada siswa kelas 1 sekolah dasar. Dengan adanya penelitian ini diharapkan dapat menjadi bahan refleksi terhadap implementasi proses pembelajaran PPKn dan juga sebagai masukan untuk meningkatkan proses pembelajaran di kelas. Selain itu digunakan sebagai acuan dalam bidang penelitian sejenis secara lebih mendetail dan mendalam.

\section{METODE PENELITIAN}

Penelitian ini menggunakan pendekatan penelitian kualitatif karena menyajikan data yang bersifat deskriptif yaitu berupa kata-kata dan bahasa, namun disertai data angka untuk menguji kredibilitas suatu data. Penelitian ini menyajikan deskripsi tentang kemampuan siswa dalam menyusun puzzle pada materi simbol-simbol Pancasila. Tempat penelitian ini di SDN Gayam 3 Kota Kediri. Subjek penelitian ini adalah siswa kelas 1 SDN Gayam 3 Kediri dengan jumlah siswa 18 laki - laki dan 10 perempuan.

Data yang diperlukan dalam penelitian ini menggunakan teknik pengumpulan data yakni observasi, catatan lapangan dan dokumentasi. Observasi dilakukan dengan dua cara yaitu observasi pada guru guna mengetahui kendala apa saja yang dialami guru saat pembelajaran berlangsung, serta observasi siswa guna mengetahui tingkat kemampuan siswa dalam menempelkan atau menyusun puzzle simbol-simbol pada garuda Pancasila serta observasi dalam mencocokkan simbolsimbol Pancasila dengan bunyi Pancasila. Kemudian catatan lapangan digunakan untuk memberikan gambaran secara nyata saat proses pembelajaran berlangsung dan dapat menjadi bahan refleksi pada penelitian ini. Selanjutnya dokumentasi digunakan sebagai bukti fisik dalam pengambilan data.

Teknik analisis data yang digunakan dalam penelitian ini terdiri atas tiga tahap yaitu reduksi data, penyajian data, dan penarikan kesimpulan. Pada reduksi data, peneliti memilah data yang sesuai dengan tujuan penelitian yakni kemampuan siswa dalam menempelkan atau menyusun puzzle simbol-simbol Pancasila dan mencocokkan simbol-simbol Pancasila dengan bunyi sila Pancasila. Setelah dipilah sesuai tujuan penelitian, dilakukan penyajian data yakni menggunakan penskoran pada lembar observasi guru dan siswa. Selanjutnya dilakukan penarikan kesimpulan dari hasil observasi guru dan siswa, catatan lapangan, dan dokumentasi.

Kemudian Pengujian kredibilitas data, dilakukan dengan menggunakan triangulasi yang didasarkan pada sumber data, metode, dan peneliti. Triangulasi yang digunakan peneliti adalah:

1. Triangulasi Sumber untuk menguji kredibilitas data dilakukan dengan cara mengecek data yang telah diperoleh melalui beberapa sumber. Peneliti menggali informasi dari guru serta siswa. Data dari sumber-sumber tersebut dideskripsikan, dikategorisasikan, mana yang memiliki pandangan sama, yang berbeda, dan mana yang spesifik. 
2. Triangulasi Data untuk menguji kredibilitas data dengan cara mengecek data baik berupa data kuantitatif dan kualitatif. Dalam penelitian ini, triangulasi yang dilakukan yakni kepada siswa kelas I SDN Gayam 3 Kediri. Waktu penelitian dilakukan pada bulan Januari 2020.

\section{HASIL PENELITIAN DAN PEMBAHASAN}

\section{Hasil Observasi}

Pada kegiatan penelitian dilakukan pengamatan yang dilakukan oleh observer dengan menggunakan lembar pengamatan guru dengan siswa dengan aspek-aspek yang diteliti dan memberikan nilai sesuai dengan ketentuan yang sudah dicantumkan dalam lembar pengamatan.

\section{a. Observasi Guru}

Berdasarkan hasil pengamatan observer dengan menerapkan metode kooperatif tipe STAD, aktivitas guru selama proses pembelajaran berlangsung sudah baik, akan tetapi cara mengajar guru belum sesuai dengan langkah-langkah pembelajaran yang sesuai dengan Rencana Pelaksanaan Pembelajaran sehingga sebagian siswa bingung dalam pengerjaan Lembar Kerja Siswa maupun lembar evaluasi.

Tabel 1. Data Aktivitas Guru dalam Menerapkan Model STAD

\begin{tabular}{|c|c|c|c|c|c|}
\hline \multirow{2}{*}{ No } & \multirow{2}{*}{ Aspek yang diamati } & \multicolumn{2}{|c|}{ Pengamat } & \multirow{2}{*}{$\begin{array}{l}\text { Rata- } \\
\text { rata }\end{array}$} & \multirow{2}{*}{ Persentase (dalam \%) } \\
\hline & & $\mathbf{P . 1}$ & P.2 & & \\
\hline 1. & Melakukan apersepsi & 3 & 3 & 3 & 75 \\
\hline 2. & $\begin{array}{l}\text { Menyampaikan tujuan } \\
\text { Pembelajaran }\end{array}$ & 2 & 3 & 2,5 & 62,5 \\
\hline 3. & $\begin{array}{l}\text { Membentuk kelompok } \\
\text { secara heterogen di } \\
\text { kelas }\end{array}$ & 3 & 4 & 3,5 & 87,5 \\
\hline 4. & $\begin{array}{l}\text { Menyampaikan materi } \\
\text { simbol-simbol } \\
\text { Pancasila }\end{array}$ & 4 & 3 & 3,5 & 87,5 \\
\hline 5. & $\begin{array}{l}\text { Membimbing siswa } \\
\text { dalam menyusun atau } \\
\text { mencocokan simbol- } \\
\text { simbol Pancasila. }\end{array}$ & 3 & 2 & 2,5 & 62,5 \\
\hline 6. & $\begin{array}{l}\text { Membimbing siswa } \\
\text { dalam } \\
\text { mempresentasikan } \\
\text { hasil diskusi dari tiap- } \\
\text { tiap kelompok }\end{array}$ & 4 & 3 & 3,5 & 87,5 \\
\hline 7. & Guru memberi evaluasi & 2 & 3 & 2,5 & 62,5 \\
\hline 8. & $\begin{array}{l}\text { Membimbing siswa } \\
\text { dalam menyimpulkan } \\
\text { materi simbol-simbol } \\
\text { Pancasila }\end{array}$ & 2 & 3 & 2,5 & 62,5 \\
\hline 9. & $\begin{array}{l}\text { Memberikan } \\
\text { penghargaan dengan } \\
\text { memberikan reward }\end{array}$ & 3 & 3 & 3 & 75 \\
\hline \multicolumn{2}{|c|}{ Jumlah } & 26 & 27 & 26,5 & \\
\hline \multicolumn{2}{|c|}{ Rata-rata } & 2,8 & 3 & 2,9 & \\
\hline \multicolumn{2}{|c|}{ Presentase (dalam \%) } & 72 & 75 & 73,6 & \\
\hline
\end{tabular}


Dari aktivitas guru pada tabel 1 menunjukkan persentase $73,6 \%$. Hal ini belum dapat dikategorikan berhasil karena belum mencapai ketuntasan klasikal yakni 80\%. Hal ini dikarenakan guru belum sepenuhnya melaksanakan pembelajaran yang sesuai dengan rencana pelaksanaan pembelajaran (RPP), sehingga banyak penerapan dari model pembelajaran STAD yang tidak terlaksana.

Aspek melakukan apersepsi cukup terlaksana dengan baik yaitu memperoleh persentase 75\%. Pada apersepsi guru hanya menyanyi bersama dengan siswa terkait materi Pancasila, namun guru tidak melakukan tanya jawab masalah kehidupan sehari-hari siswa dengan materi yang akan diajarkan agar guru mampu mengarahkan perhatian siswa.

Aspek menyampaikan tujuan pembelajaran belum dilaksanakan dengan baik, guru hanya memperoleh persentase 62,5\%. Dalam pembelajaran guru menyampaikan tujuan sesuai KD, namun guru tidak menyampaikan tujuan pembelajaran secara lengkap dan tidak menyampaikan tujuan secara runtut dan sistematis. Pada saat menyampaikan tujuan pembelajaran, guru masih ragu-ragu dan terlihat belum ada kesiapan dalam mengajar.

Aspek membentuk kelompok siswa secara heterogen di kelas sudah dilaksanakan dengan maksimal dengan persentase $87,5 \%$. Terbukti guru dalam membentuk kelompok sudah sesuai dengan model STAD yaitu membagi siswa dalam beberapa kelompok dengan tiap-tiap kelompok beranggotakan 5-6 siswa, pembagian kelompok juga disesuaikan dengan tingkat intelektualnya dan guru ikut serta dalam mengatur tempat duduk secara berkelompok.

Aspek menyampaikan materi simbol-simbol Pancasila sudah baik yaitu dengan persentase 87,5\%. Guru dalam menjelaskan materi sudah sesuai dengan sistematika dalam pembelajaran. Kegiatan guru dalam pembelajaran saat menyampaikan materi yakni guru menjelaskan simbolsimbol Pancasila yang terdapat pada Garuda Pancasila, kemudian guru menjelaskan hubungan antara simbol-simbol Pancasila dengan sila-sila Pancasila.

Aspek membimbing siswa dalam kelompok belajar memperoleh nilai 62,5\% dari seluruh aktivitas. Dalam aktivitas guru masih belum dikatakan berhasil, karena guru tidak menjelaskan atau memberi petunjuk cara pengerjaan LKS secara lisan ataupun dengan simulasi yang berisi menyusun puzzle simbol-simbol Pancasila pada semua kelompok. Petunjuk pengerjaan hanya ada di LKS saja, sehingga banyak siswa yang mengalami kesulitan saat mengerjakannya.

Aspek membimbing siswa dalam mempresentasikan hasil diskusi dari tiap-tiap kelompok sudah sangat baik, dalam aspek ini guru memperoleh nilai $87,5 \%$ dari semua indikator aktivitas. Guru sudah melaksanakan RPP dengan baik yaitu guru meminta semua anggota kelompok untuk mempresentasikan hasil diskusinya mengenai menyusun puzzle simbol-simbol Pancasila secara bergantian dengan runtut dan jelas, guru memberi kesempatan kelompok lain untuk memberi tanggapan, saran maupun masukan dari penyaji, serta guru bersama siswa menyimpulkan hasil diskusi secara bersama-sama.

Aspek memberi evaluasi di akhir pembelajaran mendapatkan nilai 62,5\%, aspek ini masih belum terlaksana secara penuh. Dalam pembelajaran guru hanya membagi soal evaluasi saja, tidak memberi pengarahan dan mengawasi siswa dalam mengerjakan evaluasi.

Aspek membimbing siswa dalam menyimpulkan materi simbol-simbol Pancasila mendapatkan nilai 62,5\% dari semua aktivitas. Dalam menyimpulkan materi di akhir pembelajaran, guru masih belum melaksanakannya dengan baik. Hal ini terbukti guru hanya menyimpulkan materi secara bersama-sama dengan siswa, namun tidak membimbing siswa dalam menyimpulkan materi dengan kalimatnya sendiri dan sesuai dengan materi pembelajaran. Verbalisme dari guru masih sangat dominan sehingga siswa kurang dominan saat menyimpulkan

Aspek memberikan penghargaan dengan memberikan reward mendapatkan nilai $75 \%$ dari seluruh aktivitas. Penghargaan kepada siswa dilakukan dengan cukup baik, namun ada yang masih belum terlaksana. Guru dalam pembelajaran memberikan reward berupa kertas senyum dan pemberian kepada siswa yang aktif selama pembelajaran.

\section{b. Observasi Siswa}

Pada saat pembelajaran PPKn dengan materi simbol-simbol Pancasila dilakukan pengamatan kepada siswa guna mengetahui kemampuan siswa dalam menyusun puzzle dengan model STAD. 
Tabel 2. Data Aktivitas Siswa dalam Menyusun Puzzel Simbol-Simbol Pancasila

\begin{tabular}{|c|c|c|c|c|c|}
\hline \multirow{2}{*}{ No } & \multirow{2}{*}{ Aspek yang diamati } & \multicolumn{2}{|c|}{ Pengamat } & \multirow{2}{*}{$\begin{array}{l}\text { Rata- } \\
\text { rata }\end{array}$} & \multirow{2}{*}{$\begin{array}{c}\text { Presentase } \\
\text { (dalam \%) }\end{array}$} \\
\hline & & P.1 & P.2 & & \\
\hline 1. & $\begin{array}{l}\text { Memperhatikan penjelasan } \\
\text { Guru }\end{array}$ & 3 & 2 & 2,5 & 62,5 \\
\hline 2. & $\begin{array}{l}\text { Ketepatan dalam menyusun } \\
\text { puzzle simbol-simbol } \\
\text { Pancasila }\end{array}$ & 3 & 2 & 2,5 & 62,5 \\
\hline 3. & $\begin{array}{l}\text { Kerapian dalam menyusun } \\
\text { puzzle simbol-simbol } \\
\text { Pancasila }\end{array}$ & 3 & 2 & 2,5 & 62,5 \\
\hline 4. & $\begin{array}{l}\text { Kerjasama dalam } \\
\text { menyusun puzzle simbol- } \\
\text { simbol Pancasila }\end{array}$ & 3 & 3 & 3 & 75 \\
\hline 5 & $\begin{array}{l}\text { Menyajikan hasil diskusi di } \\
\text { depan kelas dengan baik }\end{array}$ & 3 & 2 & 2,5 & 62,5 \\
\hline 6. & $\begin{array}{l}\text { Menyimpulkan materi } \\
\text { bersama dengan guru }\end{array}$ & 3 & 2 & 2,5 & 62,5 \\
\hline & Mengerjakan soal evaluasi & 3 & 2 & 2,5 & 62,5 \\
\hline & Jumlah & 21 & 15 & 18 & 450 \\
\hline & Rata-rata & 3 & 2,1 & 2,5 & 64,2 \\
\hline
\end{tabular}

Pada kegiatan menyusun puzzle simbol-simbol pancasila pada tabel 2, menunjukkan persentase dari seluruh aspek yaitu 64,2\%. Hal ini belum dikategorikan tuntas karena tidak mencapai ketuntasan klasikal yaitu 80\%. Aspek memperhatikan penjelasan guru mendapatkan nilai $62,5 \%$. Pada kegiatan ini masih sangat rendah, banyak siswa yang tidak mendengarkan dengan cermat penjelasan dari guru, banyak anak yang ramai saat pembelajaran berlangsung sehingga tidak fokus saat pembelajaran. Tetapi sebagian siswa sudah aktif dalam bertanya dan menjawab pertanyaan dari guru mengenai simbol-simbol Pancasila.

Aspek ketepatan dalam menyusun puzzle simbol-simbol Pancasila dalam pembelajaran cukup baik yakni mendapatkan persentase 62,5\%. Dari 5 kelompok yang dibagi guru saat pengerjaan menyusun puzzle simbol-simbol Pancasila, 2 kelompok belum tepat dalam menyusun puzzle karena masih belum hafal dengan letak simbolnya dan masih bingung simbol-simbolnya harus ditempatkan dimana. Dua kelompok tersebut masih melirik pekerjaan dari kelompok lain.

Aspek kerapian dalam menyusun puzzle simbol-simbol Pancasila mendapatkan persentase 62,5\% dari seluruh aktivitas. Pada saat menyusun puzzle simbol-simbol Pancasila, siswa belum rapi dalam memasangkan simbol-simbol Pancasila pada tempatnya, karena masih kelas 1 SD siswa belum bisa mandiri saat menyusun sehingga masih perlu bimbingan intensif oleh guru.

Aspek kerjasama dalam menyusun puzzle simbol-simbol Pancasila sudah baik dalam pembelajaran di kelas yakni mendapatkan nilai $75 \%$ dari semua aktivitas. Hal ini dikarenakan saat pembelajaran berlangsung siswa antusias dalam mengerjakan LKS yaitu menyusun puzzle simbolsimbol Pancasila. Mereka kompak saat menyusun puzzle tersebut walaupun ada yang salah, ada yang masih bingung melihat pekerjaan kelompok lain, ada yang tidak rapi menyusunnya atau saling usil dengan temannya, dan mencoret-coret buku dan lain-lain.

Aspek menyajikan hasil diskusi di depan kelas dengan baik dilakukan oleh siswa namun masih belum dikatakan mencapai indikator keberhasilan yaitu mencapai persentase 62,5\%. Dikarenakan siswa banyak yang belum berani tampil ke depan kelas, masih malu-malu, bahkan ada yang menangis saat disuruh guru untuk menyajikan hasil kerja kelompoknya. Siswa belum terbiasa berbicara di muka kelas sehingga perlu bimbingan intesif dari guru agar siswa kelas 1 lebih berani dan percaya diri saat tampil di muka kelas. 
Aspek menyimpulkan materi bersama guru, dari aktivitas siswa masih belum dikategorikan tinggi yaitu dengan persentase 62,5\%. Dalam kelas siswa menyimpulkan materi dengan katakatanya sendiri namun perlu bimbingan dari guru.

Aspek mengerjakan soal evaluasi masih belum dikatakan kategori tinggi yaitu $62,5 \%$ dari seluruh aktivitas. Banyak siswa dalam mengerjakan soal tidak teliti. Namun siswa mengerjakan dengan sendiri dan siswa menyelesaikan dengan tepat waktu saat pengumpulan soal evaluasi.

\section{Hasil Catatan Lapangan}

Catatan Lapangan selama pembelajaran menunjukkan guru telah menerapkan pembelajaran STAD dengan langkah-langkahnya sebagai berikut: (1) pembagian kelompok, (2) penyampaian materi, (3) diskusi kelompok, (4) pemberian kuis/pertanyaan, (5) penyimpulan, (6) pemberian penghargaan (Wibowo, 2016). Pembagian kelompok dengan cara membagi siswa menjadi beberapa kelompok yang setiap kelompoknya terdiri dari 4-5 siswa yang memprioritaskan heterogenitas (keragaman) kelas dalam prestasi akademik, jenis kelamin, ras atau etnik (fungsi utama dari tim yang heterogen ialah memastikan bahwa semua anggota dapat belajar dengan baik.

Pada suatu kelompok, ada pembagian tugas untuk setiap anggotanya. Hal ini menyebabkan tiap anggota bergantung satu sama lain dalam menyelesaikan permasalahan yang diberikan oleh guru. Dalam sebuah kelompok, siswa akan saling menghargai, tumbuh rasa percaya diri, penerimaan terhadap anggota kelompok yang kurang secara akademik, dan perasaan memiliki atas kelompok tersebut. Pada kegiatan berkelompok, kelompok diminta untuk menyusun puzzel dengan materi simbol-simbol Pancasila berdasarkan petunjuk pengerjaan LKS.

Penyampaian materi dari guru mengenai simbol-simbol Pancasila dan sila-sila Pancasila dengan media gambar garuda Pancasila. Kegiatan selanjutnya dilakukan dengan tanya jawab mengenai sila-sila Pancasila dan menghubungkan antara simbol-simbol Pancasila yang ditunjukkan guru. Kemudian guru menyampaikan tugas ataupun pekerjaan yang harus dikerjakan disertai caracara untuk mengerjakannya. Kegiatan belajar dalam kelompok akan terlaksana ketika siswa belajar dalam kelompok yang telah dibentuk guru, dan siswa melaksanakan kerja kelompok berupa menyusun puzzle simbol-simbol Pancasila. Selama kelompok bekerja, guru melakukan pengamatan, memberikan bimbingan, dorongan dan bantuan apabila diperlukan oleh siswa. Kerja kelompok merupakan ciri terpenting dari STAD. Mengerjakan evaluasi yang dilakukan oleh setiap siswa dengan pemberian soal pilihan ganda sebanyak 5 butir, uraian 5 butir dan isian 5 butir dengan mengacu indikator kognitif yang terdapat pada RPP. Evaluasi dilaksanakan di akhir pertemuan dari hasil kerja setiap siswa untuk memperoleh gambaran secara nyata hasil dari pembelajaran yang dilakukan guru kepada siswa.

Reward atau penghargaan prestasi kelompok dengan cara guru memeriksa hasil kerja kelompok yakni mengerjakan puzzle simbol-simbol Pancasila dan mepresentasikannya di kelas. Penghargaan diberikan kepada kelompok yang tepat menyusun puzzle dengan skor 91-10o dengan pemberian hadiah berupa pensil kepada setiap anggota kelompok, kemudian bagi kelompok yang kurang tepat dalam menyusun puzzle dengan skor 81-90 dengan pemberian hasiah berupa penghapus kepada setiap anggota kelompok. Pertimbangan diberikannya berupa barang karena menurut gurunya anak-anak suka dan semangat diberi hadiah yang tampak mata bukan hanya sekedar nilai saja. Sesuai dengan pendapat Rusman (2012) bahwa penghargaan dapat diberikan kepada siswa bisa dalam bentuk tambahan nilai atau materi lainnya seperti hadiah yang disukai oleh peserta didik.

Guru juga menggunakan media yang sesuai dengan materi pelajaran yakni gambar garuda pancasila dalam bentuk bongkar pasang sterofoam agar mudah mengingat materi yang diajarkan yakni simbol-simbol Pancasila. Kemudian penataan tempat duduk juga telah baik, semua siswa tidak ada yang membelakangi papan tulis.

\section{Dokumentasi}

Dokumentasi dalam bentuk foto kegiatan-kegiatan yang dilakukan oleh guru dan siswa saat pembelajaran berlangsung. Foto digunakan untuk menambah bukti fisik bahwa telah melakukan penelitian untuk menganalisis kemampuan siswa sekolah dasar kelas 1 di SDN Gayam 3 Kediri dalam menyusun puzzle simbol-simbol Pancasila dala materi PPKn. 


\section{SIMPULAN}

Berdasarkan hasil penelitian dengan mengacu pada instrumen penelitian berupa data hasil observasi guru dengan persentase $73,6 \%$ kemudian observasi aktivitas siswa dengan persentase $64,2 \%$, selanjutnya berdasarkan hasil catatan lapangan dan dokumentasi dinyatakan bahwa siswa kelas 1 SDN Gayam 3 Kediri telah mampu menyusun puzzle simbol-simbol Pancasila dengan materi PPKn meskipun masih terdapat kekurangan-kekurangan. Kekurangan tersebut dari guru, saranaprasarana sekolah, dan siswa sendiri.

Kekurangan dari guru yakni kurang sabar, kurang telaten, kurang detail dalam menjelaskan materi simbol-simbol Pancasila. LKS yang diberikan pada tiap-tiap kelompok tidak disertai penjelasan secara verbal melainkan hanya ditulis di LKS saja, sehingga ada 2 kelompok yang masih bingung mengerjakan LKS tersebut. Sehingga saat presentasi, dua kelompok tersebut tidak mendapatkan hasil maksimal. Kekurangan dari sarana dan prasarana sekolah yakni tidak ada LCD atau proyektor sehingga media yang digunakan minim. Media pembelajaran yang digunakan yakni media gambar. Sebaiknya selain media, perlu ditampilkan pula media PPT atau video yang menarik agar siswa lebih tertarik dengan materi Pancasila agar pembelajaran tidak monoton atau membosankan bagi siswa. Kemudian kekurangan dari siswa yakni siswa ramai saat pembelajaran, banyak anak yang menyanyi-menyanyi dan klotekan saat pembelajaran. Sehingga pembelajaran kurang kondusif dan banyak anak yang kurang memahami materi yang disampaikan guru.

\section{DAFTAR PUSTAKA}

Esminarto, dkk. (2016). "Implementasi Model STAD dalam Meningkatkan Hasil Belajar Siswa”. Briliant: Jurnal Riset dan Konseptual Volume 1 Nomor 1, November 2016. Diakses pada tanggal 29 Desember 2020.

Fauzia, Zulfa. 2020. “Memasangkan Benda Sesuai engan Pasangannya”. Paper Universitas Negeri Yogyakarta. Diakses dari academia.edu pada 04 April 2020.

Hastuti, Winda. (2019). "Peningkatan Hasil Belajar PPKn Menggunakan Media Puzzle Pancasila pada Siswa Kelas IA di SD Negeri Rambutan 03 Pagi”. Seminar Nasional Pendidikan dan Call for Papers (SNDIK). Jakarta Timur, Universitas Muhammadiyah Surakarta. Diakses dari google cendekia pada 20 Februari 2020

Ibda, Fatimah. 2012. "Pendidikan Moral Anak Melalui Pengajaran Bidang Studi PPKn dan Pendidikan Agama”. Jurnal Ilmiah DIDAKTIKA Februari 2012, vol. 12 no. 2, halaman 338347.

Kawuryan, Sekar Purbarini. (2011). “Karakteristik Siswa SD Kelas Rendah dan Pembelajarannya”. Pengabdian PPSD FIP Universitas Negeri Yogyakarta. Diakses dari google cendekia pada 03 April 2020.

Latut, Anirisa. (2017). "Penggunaan Media Puzzle untuk Meningkatkan Hasil Belajar Siswa pada Pembelajaran IPS di Kelas IV MIN Lambaro Aceh Besar”. Skripsi. Banda Aceh, Universitas Islam Negeri Ar-Raniry Darussalam Banda Aceh: Tidak Diterbitkan.

Rusman. (2012). Model-Model Pembelajaran Mengembangkan Profesionalisme Guru. Jakarta PT. Rajagrafindo Persada.

Solichah, Imroatus. (2016). “Kegiatan Menempel Kolase Sederhana Terhadap Kemampuan Motorik Halus Anak Tunagrahita Sedang di SLB C”. Jurnal Pendidikan Khusus. Universitas Negeri Surabaya. Diakses dari google cendekia pada 03 April 2020. 
Yunita, W. (2016). Improving Students' Speaking Skill By Using STAD (Student Teams Achievement Divisions). AL-ISHLAH: Jurnal Pendidikan, $\quad$ 8(1), 136-153. doi:https://doi.org/10.35445/alishlah.v8i1.35

Wibowo, et.al. (2016). Penerapan Model Kooperatif Tipe STAD dalam Peningkatan Pembelajaran Bangun Datar pada Siswa Kelas V SD. Kalam Cendekia PGSD Kebumen, (Online), 4(1): 1 7. (http://jurnal.fkip.uns.ac.id/index.php/pgsdkebumen/article/view/2058), diakses 7 November 2016. 